\title{
PENGARUH BUDAYA KONSUMERISME TERHADAP MASYARAKAT KOTA
}

\author{
Tedy Wiraseptya , Melisa Suardi
}

\author{
,Universitas Putra Indonesia YPTK Padang \\ tedyibob@yahoo.co.id, melisasuardi@gmail.com
}

\begin{abstract}
Abstrak
Urban society as modern society does not only consume functional basic needs to survive. But fulfilling needs that are becoming a desire of urban society. The birth of the culture of consumerism is currently making rapid changes to the city community. However, not all urban communities accept this change. therefore, it is not uncommon to fight arguments and violence resulting from changes in consumerism. This culture of consumerism is motivated by the emergence of a period of capitalism which is carried by liberalism. The emergence of a culture of consumerism has a positive and negative impact. Has a positive impact when the employment field increases, the birth of new technology and others. The negative is when hedonism, consumerism, capitalism, and others arise.
\end{abstract}

Keywords: City Society, Culture, Consumerism

\section{PENDAHULUAN}

Masyarakat kota ialah masyarakat modern yang termasuk masyarakat konsumtif. Konsumsi masyarakat kota tidak lagi hanya sekedar mengkonsumsi secara fungsional kebutuhan pokok dalam bertahan hidup. Setidaknya lebih dari itu, bahwa masyarakat kota memenuhi kebutuhan yang sedang menjadi keinginan masyarakat urban. Misalkan produk yang sedang hits dan di pasarkan oleh artis papan atas.

Konsumsi masyarakat perkotaan secara tidak langsung diatur oleh kebijakan-kebijakan pasar. Ini terbukti dari peperangan daya saing antar perusahaan menengah keatas untuk menjual produk mereka.

Lahirnya budaya konsumerisme saat ini membuat perubahan secara cepat pada masyarakat kota. Dampak percepatan teknologi adalah salah satu yang melandasi perubahan tersebut. Namun, tidak semua masyarakat kota bisa menerima perubahan ini secara langsung. Karena itu, tidak jarang adu argument dan kekerasan terjadi akibat perubahan yang terjadi pada konsumerisme dalam masyarakat perkotaan.

Keadaan yang tidak serasi itu mengakibatkan gesekan-gesekan negatif. Hal ini juga terjadi karna masuknya unsur budaya asing yang belum dapat di terima masyarakat secara wajar. Ketakutan masyarakat tentunya menjadi kewajaran hingga pemerintah melihat hal-hal itu dengan penyesuaian perda hingga undang-undang yang berlaku.

Dengan maraknya teknologi maka semua menjadi dua sisi, antara sisi positif dan sisi negatif. Maka yang paling di untungkan dalam segi konsumerisme adalah para kaula muda dan para kalangan menengah keatas. Tapi, para pemodal pasar melihat sisi terbalik dari kesenjangan tersebut. Hingga banyaknya lahir media yang mendukung teknologi bagi kalangan menengah kebawah.

Media sosial adalah salah satu faktor yang membuat masyarakat modern menjadi konsumen yang loyal. Misalkan penggunaan aplikasi youtube di Instagram Indonesia bahkan telah 
mencapai puluhan juta pengunduh. Ini adalah bukti bahwa masyarakat modern sudah menjadikan media sosial sebuah kebutuhan bersanding dengan kebutuhan pokok.

\section{TINJAUAN LITERATUR}

Masyarakat modern mempunyai ciri khas dalam gaya hidup. Gaya hidup adalah pola-pola tindakan yang membedakan antara satu ornag dengan orang lainnya. Pola-pola sosial yang khusus sering kali di sederhanakan dengan istilah budaya. Karna, bentuk-bentuk kultural, moral, konsumsi barang, tempat dan waktu merupakan sebuah karakteristik pada suatu kelompok.

Konsumtif lebih khusus menjelaskan keinginan untuk mengkonsumsi barang-barang yang sebenarnya kurang diperlukan secara berlebihan untuk mencapai kepuasan yang maksimal (Tambunan,2003). Perilaku konsumtif juga dapat didefenisikan sebagai perilaku membeli barang atau jasa yang berlebihan, walaupun tidak dibutuhkan (Moningka, 2006).

Perilaku konsumerisme dalam kehidupan masyarakat kota mempengaruhi gaya gaya hidup dalam sebuah kelompok. Menurut Moningka (2006), ada 3 tipe perilaku konsumtif yaitu :

1. Konsumsi adiktif (addictive consumption), yaitu mengkonsumsi barang atau jasa karena ketagihan.

2. Konsumsi kompulsif (compulsive consumption), yaitu berbelanja secara terus menerus tanpa memperhatikan apa yang sebenarnya ingin di beli.

3. Pembelian implusif (impulse buying atau impulsive buying). Pada impulse buying, produk dan jasa memiliki daya guna bagi individu. Pembelian produk atau jasa tersebut biasanya dilakukan tanpa perencanaan.

Jika seandainya kita merujuk pada pria metroseksual, menurut Kottler dan Amstrong (1997) ada beberapa faktor yang mempengaruhi perilaku dalam proses pembelian. Berdasarkan konteks pria metroseksual maka faktor-faktor yang mempengaruhi adalah :

1. Pekerjaan

Pria metroseksual kebanyakan adalah eksekutif muda. masalah penampilan jelas terlihat dari pakaian dengan segala atributnya seperti dasi, sepatu sampai parfum dan sebagainya. Faktor yang relevan dengan sisi penampilan juga ditambah dengan perawatan tubuh mulai dari salon, spa dan klub fitnes. 


\section{Situasi ekonomi}

Kartajaya,dkk (2004) mengatakan bahwa pria metroseksual biasanya berasal dari kalangan dengan penghasilan ekonomi yang besar. Besarnya materi yang dikeluarkan untuk menunjang perilaku konsumtif yang mereka lakukan bukan menjadi masalah.

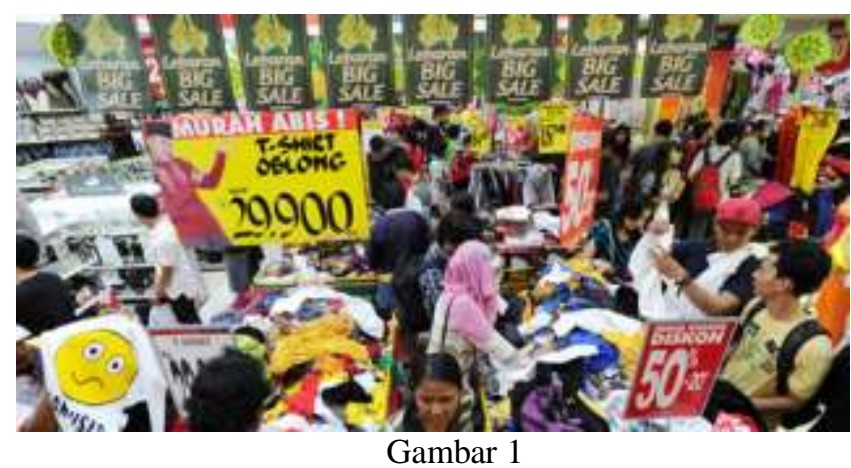

Proses belanja konsumen

Dalam istilah gaya hidup (lifestyle) sekarang ini kabur. Sementara istilah ini memiliki arti sosiologis yang lebih terbatas dengan merujuk pada gaya hidup yang khas dari berbagai kelompok status tertentu, dalam budaya konsumen kontemporer istilah ini mengkonotasikan individualitas, ekspresi diri, serta kesadaran diri yang semu. Tubuh, busana, bicara, hiburan saat waktu luang, pilihan makanan dan minuman, rumah, kendaraan, dan hiburan dan seterusnya dipandang sebagai indikator dari individualitas selera serta rasa gaya dari pemilik atau konsumen (Featherstone,Mike:2005).

Budaya konstumer diartikan sebagai bentuk budaya materi yakni budaya pemanfaatan bendabenda dalam masyarakat Eropa-Amerika kontemporer. Kini, apa yang dinikmati oleh masyarakat Eropa-Amerika kontemporer tersebut "yang notabene adalah negara kaya" di tiru oleh masyarakat dunia lain termasuk negara Indonesia. Terlebih lagi, beberapa negara juga sudah memberikan tren mereka kepada dunia. Seperti korea dan jepang.

Kaum kapitalis senantiasa menciptakan kebutuhan baru yang menjamin bahwa manusiaakan terus didoronguntuk melaksanakan jenis-jenis peranyang dibutuhkanuna mempertahankan system kapitalis. Kebutuhan senantiasa dibentuk dan diekploitasi untuk memperbesar kesediaan para konsumen menyesuaikan diri dengan persyaratan system dan mendukung bertahannya sistem itu.

Budaya konsumerisme dilatar belakangi oleh munculnya masa kapitalisme yang diusung oleh Karl Marx yang kemudian disusul dengan liberalisme. Budaya konsumen yang merupakan jantung dari kapitalisme adalah sebuah budaya yang didalamnya terdapat bentuk halusinasi, mimpi, artifisialitas, kemasan wujud komoditi, yang kemudian dikontruksi sosial melalui komunikasi ekonomi (iklan, show, media) sebagai tanda kapitalisme.

Asal konsumerisme dikaitan dengan proses industrialisasi pada awal abad ke 19. Karl Marx menganalisa buruh dan kondisi-kondisi material dari proses produksi. Menurutnya, kesadaran manusia ditentukan oleh kepemilikan alat-alat produksi. Prioritas, ditentukan ole produksi sehingga aspek lain dalam hubungan antarmanusia dengan kesadaran, kebudayaan dan politik dikatakan dikontruksikan oleh relasi ekonomi.

Kapitalisme yang dikemukakan leh Marx adalah suatu cara produksi yang dipremiskan oleh kepilikan pribadi sarana produksi. Kapitalisme bertujuan untuk meraih keuntungan sebesarbesarnya, terutama dengan mengekploitasi pekerja. Realisasi nilai surplus dalam bentuk uang 
yang diperoleh dengan menjual produk sebagai komoditas. Komoditas adalah sesuatu yang tersedia untuk dijual dipasar. Sedangkan komoditas adalah proses yang asosiasikan dengan kapitalisme dimana objek, kualitas, dan tanda berubah menjadi komoditas.

Budaya konsumsi merupakan istilah yang menyangkut tidak hanya perilaku konsumsi, tetapi adanya suatu proses reorganisasi bentuk da nisi produksi simbolik didalamnya. Perilaku disini bukan sebatas perilaku konsumen dalam artian pasif. Namun, merupakan bentuk konsumsi produktif, yang menjanjikan kehidupan pribadi yang indah dan memuaskan, menemukan kepribadian melalui perubahan diri dan gaya hidup. Budaya konsumen menekan adanya suatu tempat dimana kesan memainkan peranan utama.

Masyarakat modern adalah masyarakat konsumtif. Masyarakat yang terus menerus berkonsumsi. Hingga konsumsi telah menjadi budaya. Bagi masyarakat konsumen, saat ini hampir tidak ada ruang dan waktu tersisa untuk menghindari diri dari serbuan berbagai informasi yang berurusan dengan kegiatan konsumsi. Dirumah, dikantor, dijalan dan dimanapun masyarakat disajikan informasi yang menstimulasikan konsumsi melalui media.

Menurut Yasraf Amir Piliang, fenomena yang menonjol dalam masyarakat Indonesia saat ini yang menyertai kemajuan ekonomi adalah berkembangnya budaya konsumsi yang ditandai dengan berkembangnya gaya hidup.

Berkembangya gaya hidup masyarakat perkotaan satu sisi bisa menjadi pertanda positif meningkatnya kesejahteraan hidup masyarakat kota. Dimana peningkatan kegiatan konsumsi dipandang sebagai efek naiknya penghasilan dan taraf hidup. Namun disisi lain, fenomena tersebut juga bisa dikatakan pertanda kemunduran rasionalitas masyarakat, yang mana konsumsi dianggap sebagai faktor yang menyebabkan hilangnya kritisme masyarakat terhadap berbagai hal yang vital bagi kehidupan, kebijakan pemerintah dan yang lainnya.

\section{METODOLOGI}

Pengaruh konsumerisme pada masyarakat pada masyarakat kota bisa menjadi dampak positif dan dampak negatif. Penggunaan metode kulitantif dalam melihat perubahan pola tingkah laku, pola kegiatan dan pola kehidupan masyarakat kota menunjukkan bahwa masyrakat kota secara kebutuhan kehidupan memang merujuk pada konsumerisme karena khidupan yang liberal.

Menurut Assael (1992) mengelompokkan faktor lingkungan yang mempengaruhi konsumen terdiri atas budaya dan kelas social, pengaruh sub-budaya, pengaruh global dan lingtas budaya, pengaruh kelompok rujukan, pengaruh klomunikasi dalam kelompok, pengaruh keluarga, pengaruh komunikasi antar kelompok, pengaruh situasional.

\section{HASIL DAN PEMBAHASAN}

Perkembangan televisi global sebagai bangunan bisnis utama telah menempatkan budaya konsumen, iklan berbasis visual, dibarisan depan aktivitasnya (Mattelart : 1992).

Media sosial sebagai dampak yang sangat signifikan dalam perkembangannya mempengaruhi masyarakat modern. Tentunya terlihat dampak menjadi dua sisi antara positif dan negatif. Menurut Chris Garret, Media sosial adalah alat, jasa, dan komunikasi yang memfasilitasi hubungan antara orang satu dengan yang lain serta memiliki kepentingan atau ketertarikan yang sama. 


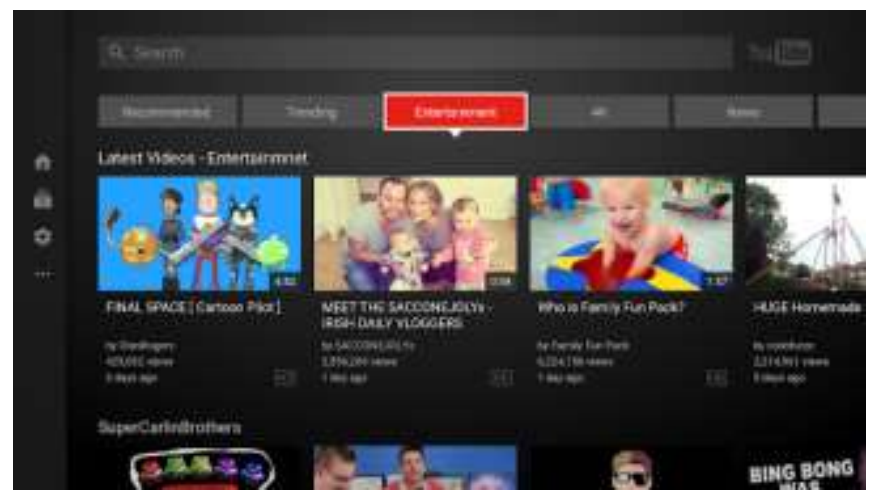

Gambar 2

Sumber: Youtube.com

Penggunaan media teknologi dalam kehidupan sudah menjadi kebutuhan primer diluar dari kebutuhan yang seharusnya. Seperti youtube.com telah berkembang pesat pada generasi masyarakat modern. Para penikmat youtube.com sudah menjadikan diri mereka sebagai konsumen terbaik dan di tonton seperti layaknya artis.

Aplikasi pada smartphone sudah menjadi kebutuhan yang mendasar dalam kehidupan. Semua aplikasi dalam media digital didukung untuk menjadikan seorang terpopuler. Masyarakat modern memburu hal tersebut hingga menginginkan keuntungan seperti orangorang yang sudah berkarir lama dan dikenal di media sosial.

Perubahan gaya hidup masyarakat modern telah berkembang dari masa- ke masa dilihat dari berkembangnya teknologi. Oleh sebab itu lagi-lagi penulis bisa menyimpulkan bahwa budaya konsumerisme masyarakat perkotaan tidak saja sebagai produk prilaku ekonomi, tetapi juga sebagai produk budaya yang lahir dari suatu tatanan sistematis sebagai dampak dari neoliberalisme.

Budaya konsumen dilatarbelakangi oleh munculnya masa kapitalisme yang susung oleh Karl Marx yang kemudian disusul dengan liberalism. Budaya konsumen merupakan suatu hal yang menarik untuk dikaji karena terkait dengan budaya pop, karena budaya konsumen ini juga mengacu pada budaya pop dengan sifatnya yang massal.

\section{KESIMPULAN}

Munculnya budaya konsumen menimbulkan dampak positif maupun negatif. Dampak positifnya adalah pembaharuan hingga bertambahnya lapangan pekerjaan karna timbulnya hal-hal yang baru. Kemudian, hal negatifnya munculnya hedonisme, konsumerisme, kapitalisme, dan budaya-budaya yang dikonsumsi cendrung mengalihkan pekerjaan-pekerjaan yang lebih penting.

\section{Referensi}

[1] Assael. 1992. Consumer Behavior. Edisi Bahasa Indonesia. New Jersey: PrenticeHall Inc.

[2] Barker, Chris. 2004. Cultural Studies, Teori dan Praktik. Yogyakarta: Kreasi Wacana.

[3] Featherstone, Mike. 2005. Posmodernisme dan Budaya Konsumen. Yogyakarta: Pustaka Pelajar 
[4] Tulus Tambunan, 2003. Perkembangan Sektor Pertanian di Indonesia, Beberapa Isu Penting. Ghalia Indonesia Jakarta.

[5] Moningka, C. 2006. Komsumtif: antara Gengsi dan Kebutuhan. (http://www.suarapembaruan.com/News/2006/12/13/urban/urb02.htm)

[6] Amstrong, G. \& Kotler. P. 1997. Prinsip-prinsip pemasaran. Cetakan pertama. Jakarta: Erlangga.

[7] Kartajaya. Hermawan. 2004. Hermawan Kartajaya on Branding. Bandung: Mizan Pustaka

[8] http://sosiologibudaya.wordpress.com/2011/05/17/budaya-konsumen/\#more-133

[9] http://eprints.undip.ac.id/9820/1/POSMODERNISME_DAN_BUDAYA_KONSUMEN.doc

[10] http://novian-r-p-fisip08.web.unair.ac.id/artikel_detail-37217-

Informasi\%20dan\%20Masyarakat-Budaya\%20Konsumen.html 